\title{
Multixenobiotic resistance protein expression in Mytilus edulis, M. galloprovincialis and Crassostrea gigas from the French coasts
}

\author{
C. Minier ${ }^{1,3, *}$, M. N. Moore ${ }^{2}$, F. Galgani ${ }^{1}$, D. Claisse ${ }^{1}$ \\ ${ }^{1}$ IFREMER, Dept Biogéochimie et Ecotoxicologie, rue de l'Ile d'Yeu, BP 21105, 44311 Nantes, France \\ ${ }^{2}$ Plymouth Marine Laboratory (PML), Prospect Place, Plymouth, Devon PL1 3DH, UK \\ ${ }^{3}$ Present address: LEMA, University of Le Havre, BP 540, 76058 Le Havre Cedex, France
}

\begin{abstract}
Multixenobiotic resistance (MXR) is a membrane-transport mechanism that allows organisms to exclude many compounds from their cells and tissues. It is thus a first line of defence against a variety of toxic compounds. Since mussels and oysters possess MXR proteins, an analysis of the expression level of these membrane-transporters has been conducted in relation to their body burden of some major environmental contaminants. Mussels Mytilus edulis and M. galloprovincialis and the oyster Crassostrea gigas were sampled from a total of 43 sites along the French coasts. High expression levels were found in animals from the major French estuaries (Seine, Loire and Gironde), at a few sites in Brittany and in nearly all sites from the Mediterranean mainland coasts. Multivariate analysis of the data for both species of blue mussel did show significant differences between groups of samples. Results indicated that expression of MXR protein was strongly associated with contaminant concentrations in mussels, and that polycyclic aromatic hydrocarbons (PAHs) and polychlorinated biphenyls (PCBs) were directly correlated with MXR protein concentration. However, multivariate analysis of oysters, which were collected in less-contaminated sites, at least for organic pollutants, did not show any significant differences between MXR protein expression and contaminants. Although the results do not infer a causal linkage between mussel MXR protein, PAHs and PCBs, since many other chemical contaminants are also present at some sites, they do show clearly that MXR protein expression can be used as an indicator of pollutant exposure in blue mussels. The findings also highlight the need to use alternative analytical methods for the interpretation of complex environmental data, and that non-parametric multivariate statistical methods are appropriate for this task.
\end{abstract}

KEY WORDS: MXR · P-glycoprotein - Biomonitoring - Mytilus edulis · Mytilus galloprovincialis . Crassostrea gigas

Resale or republication not permitted without written consent of the publisher

\section{INTRODUCTION}

Mussels and oysters have gained recognition as 'indicator organisms', serving as biomonitors to detect environmental perturbations that may affect living organisms (Philips 1978, Cantillo 1998). The rationale for a bivalve sentinel system is based on several factors (Farrington et al. 1983): they are cosmopolitan, sedentary, filter feeders, relatively pollutant resistant and commercially valuable organisms. Bivalve species are concentrating and integrating chemical exposure as they filter water for food. Moreover, their biological responses and mechanisms of adaptation can be used to provide insight into the potentially detrimental effects of their surrounding environment. Consequently, much ecotoxicological research and many monitoring studies have focused on mussels and oysters (Gosling 1992, Moore et al. 2004). 
Several studies have shown that mussels and oysters possess a multixenobiotic resistance (MXR) mechanism (Minier et al. 1993, Lüdeking \& Köhler 2002) similar to the multidrug resistance (MDR) phenomenon first discovered in mammalian cells and later identified in many other organisms including bacteria, plants, fungi, invertebrates and vertebrates (Lage 2003). Characteristics of this defence system have been established in studies on mammalian cell lines isolated for resistance to a single cytotoxic drug, which subsequently were shown to be cross-resistant to numerous structurally and functionally unrelated drugs (Biedler \& Riehm 1970, Akiyama et al. 1985). The cytotoxic compounds are predominantly alkaloids and antibiotics of plant and fungal origin (Gottesman \& Pastan 1993). The pharmacological basis for the resistance appears to be decreased drug accumulation and retention, mediated by the ATP-consuming action of an integral membrane P-glycoprotein (Pgp) (Bodo et al. 2003). This transport protein, a member of a wide family of traffic ATPases termed 'ABC transporters', is always expressed in normal human tissues. Its localisation in kidney, liver, pancreas, intestine, brain and testis suggests that this protein plays a role either in preventing the absorption or, otherwise, in the transepithelial and transendothelial transport of toxic xenobiotics or endogenous metabolites (Cordon-Cardo et al. 1990, Schinkel \& Jonker 2003).

Mussels and oysters possess several ABC-related genes (Lüdeking \& Köhler 2002, Minier et al. 2002) and express 1 or 2 proteins immunologically related to mammalian Pgp (Minier et al. 1993). Bivalve cells are able to bind and transport anticancer compounds against which mammalian cells are resistant (Galgani et al. 1995, Minier \& Moore 1996). It has been proposed that these molluscan Pgp could be part of a defence system against toxic compounds including anthropogenic wastes (Smital et al. 2004). Several studies performed on mussels support this hypothesis: (1) transport of rhodamine, a fluorescent compound used to obtain preliminary indication of the occurrence of multi-drug transport activity, can be modulated in a competitive manner by environmental contaminants (reviewed in Bard 2000); (2) increased Pgp expression level and rhodamine exclusion activity can be experimentally induced by treating aquatic organisms with drugs or environmental contaminants including polycyclic aromatic hydrocarbons (PAHs) (Smital et al. 2003); (3) field studies indicate that mussel MXR protein expression or activity is related to tissue pollutant concentrations (Minier et al. 1993, Kurelec et al. 1996, Smital et al. 2003).

Since the MXR expression may be related to pollutant exposure, assessment of the tissue protein level is a potentially powerful environmental monitoring tool.
In this study we used the C219 monoclonal antibody for assessing MXR expression levels in mussels and oysters collected at 43 sites along the French coasts. Relationships between MXR expression and body burdens of some major chemicals of concern found in bivalves were evaluated.

\section{MATERIALS AND METHODS}

Cells and animals. Bivalves were collected at 43 sites along the French coasts (Fig. 1) in October and November 1993. Depending on the sites and occurrence of the species of interest, mussels Mytilus edulis (15 sites, size 4 to $5 \mathrm{~cm}$ ) and M. galloprovincialis (10 sites, size 4 to $6 \mathrm{~cm}$ ) or oysters Crassostrea gigas (18 sites, size 5 to $7 \mathrm{~cm}$ ) were sampled. Bivalves used for biological analysis were immediately frozen and kept at $-30^{\circ} \mathrm{C}$ until further processing (within $3 \mathrm{mo}$ ), while samples used to assess contaminant body burdens were first cleaned of epibiota and then depurated for $24 \mathrm{~h}$ in decanted seawater from the collection site in order to eliminate faeces and pseudofaeces. Soft tissues were removed from the shell using a stainlesssteel scalpel, homogenized in a Virtis grinder and freeze-dried. The alga Prorocentrum micans Ehrenberg, cultured in the laboratory for many generations in toxic-free medium, i.e. in filtered ( 4 and $0.2 \mu \mathrm{m}$ ) and sterilized $\left(20 \mathrm{~min}\right.$ at $120^{\circ} \mathrm{C}$ ) Provasoli enriched seawater (Provasoli et al. 1957), was used as a P-glycoprotein (Pgp) negative control (Minier et al. 1993).

Analysis of P-glycoprotein. Prorocentrum micans cells and roughly $400 \mathrm{mg}$ of each bivalve gill sample were sonicated twice for $10 \mathrm{~s}$ at $20000 \mathrm{~Hz}$ and $70 \mathrm{~W}$ in Tris-buffered saline (TBS: Tris/HCl $20 \mathrm{mM}, 137 \mathrm{mM}$ $\mathrm{NaCl}, \mathrm{pH}$ 7.6) with $2 \mathrm{mM}$ phenylmethylsulfonyl fluoride (PMSF) and $0.02 \mathrm{TUI} \mathrm{ml}^{-1}$ aprotinine. Sodium dodecyl sulphate (SDS) was then added at a final concentration of $0.1 \%$, and the homogenates were centrifuged at $4000 \times g$ for $10 \mathrm{~min}$ at $4^{\circ} \mathrm{C}$. Supernatant protein content was determined using the $\mathrm{BCA}$ protein assay reagent (Pierce) with bovine serum albumin (BSA) as a standard.

For Western blot analysis, gel electrophoresis of protein extracts $(20 \mu \mathrm{g}$ per well) was performed in $9 \%$ polyacrilamide gels containing $0.1 \%$ (w/v) SDS. Proteins were transferred to nitro-cellulose membranes at $500 \mathrm{~mA}$ for $50 \mathrm{~min}$. For dot blot analysis, $10 \mu \mathrm{l}$ of protein extracts $(2$ to $10 \mu \mathrm{g})$ were spotted onto nitro-cellulose sheets (MSI, hybridisation transfer membrane). C219 monoclonal antibody (CIS Biointernational Nantes, France) was used as primary antibody (1 $\mu \mathrm{g}$ $\mathrm{ml}^{-1}$ ). This monoclonal antibody, raised against hamster MDR carrier is specific for a highly conserved sequence among MXR proteins (Georges et al. 1990). 
MXR proteins were revealed using the enhanced chemiluminescence assay (Whitehead et al. 1979). Blots were incubated in luminol provided in the ECL ${ }^{\mathrm{TM}}$ Western blotting kit (Amersham) following manufacturer's instructions, and light emission was detected after 1 min exposure to autoradiography film. Staining responses were then quantified using a densitometer.

Ten mussel protein extracts (from 10 individuals) for each sample site were analysed. To provide semiquantitative results, each blot was loaded with $1 \mu \mathrm{g}$ of negative (algae protein extracts) and positive samples (pooled mussel extracts from Sites 6 and 40).

Chemical analysis. Analytical procedure for organic compounds included a solid-liquid (Soxhlet, hexane: acetone 80:20) extraction step on freeze-dried samples followed by adsorption chromatography on open alumina-silica columns to remove lipids and other unwanted organic material. Total PAHs were analyzed by high performance liquid chromatography with spectrofluorometric detection (Michel 1983). Organochlorine compounds, including polychlorinated biphenyls (PCBs) and dichloro-diphenyl-chloroethanes (dichloro-diphenyltrichloro-ethane, DDT, dichloro-diphenyl-dichloro-ethane, DDD, and dichloro-diphenylethane, DDE) were analyzed by gas chromatography with an electron capture detector (Luçon \& Michel 1986).
Mercury was determined by flameless atomic absorption spectrophotometry (Thibaud 1983a). The other metals (cadmium, copper, zinc and lead) were determined by atomic absorption spectrophotometry equipped with electrothermal atomisation (Thibaud 1983b).

Results of the chemical analysis are part of the data from the French mussel watch, which analyzes 43 sites along the coasts 4 times a year since 1979. Previous results corresponding to the period 1979 to 1989 and full description of the techniques used have been previously published (Claisse 1989).

Statistical analysis. MXR protein expression and contaminant data for Crassostrea gigas, Mytilus edulis and M. galloprovincialis were analysed using nonparametric multivariate analysis software, PRIMER ver. 6 (PRIMER-E Ltd, Plymouth, UK; Clarke 1999). Cluster analysis and non-metric multi-dimensional scaling (MDS) analysis, derived from Euclidean distance similarity matrices was used to visualise dissimilarities between sample groups. All data were logtransformed and normalised prior to analysis. The results were further tested for significance using analysis of similarity (PRIMER ver. 6 ANOSIM), which is analogous to a univariate ANOVA and reflects on differences between treatment groups in contrast to differences among replicates within samples (the $\mathrm{R}$

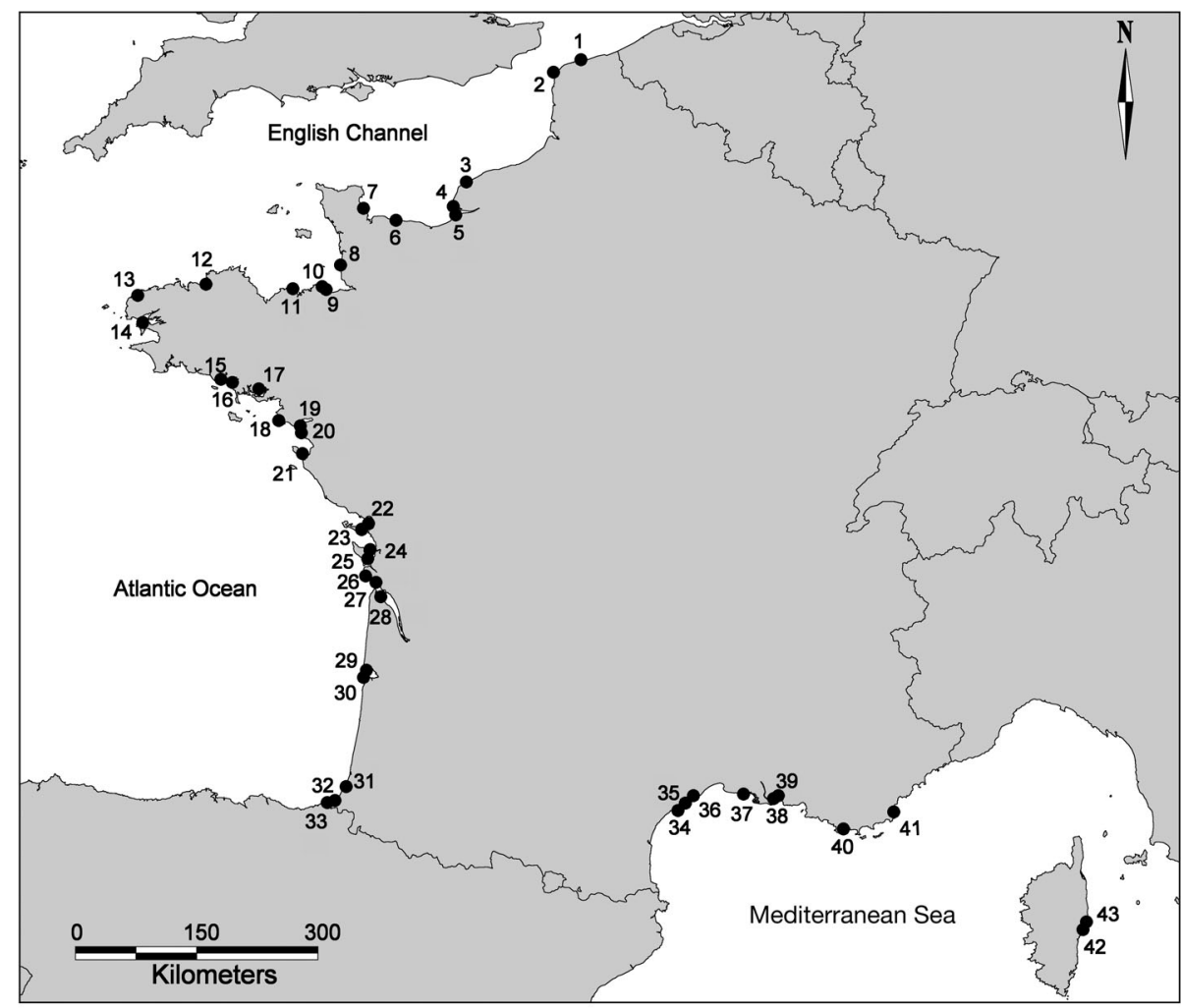

Fig. 1. Locations of sampling sites for mussels and oysters along the French coasts 
statistic). Under the null hypothosis, $H_{0}$ ('no difference between samples'), $\mathrm{R}=0$, and this was tested by a nonparametric permutations approach; there should be little or no effect on the average $\mathrm{R}$ value if the labels identifying which replicates belong to which samples are randomly rearranged (Clarke 1999).

Pairwise scatterplots (draftsman plots) were used to examine the relationships between the variables.

Finally, the PRIMER ver. 6 BIO-ENV routine linking multivariate patterns was used to identify 'influential parameters' - small subsets of MXR and chemical parameters capturing the full MDS pattern.

\section{RESULTS}

\section{Contaminant body burdens}

Sites where the oysters Crassostrea gigas were collected are characterised by high concentrations of metals that accumulated in the mollusc tissues (Table 1). Although differences in bioconcentration factors are well described between mussels and oysters (O'Connor 2002), the results highlighted the fact that the southwest coastline is highly contaminated, especially with cadmium, copper and zinc. The Gironde Estuary

Table 1. Mytilus edulis, M. galloprovincialis and Crassostrea gigas. Concentration of metals and organic pollutants along the French coasts. Total: DDD + DDE + DDT. Metals and PAH are in $\mu g g^{-1}$ dry wt; other compounds are in ng $\mathrm{g}^{-1} \mathrm{dry}_{\mathrm{wt}}$

\begin{tabular}{|c|c|c|c|c|c|c|c|c|c|c|c|c|c|}
\hline Site & $\mathrm{Cd}$ & $\mathrm{Cu}$ & $\mathrm{Hg}$ & $\mathrm{Pb}$ & $\mathrm{Zn}$ & DDD & DDE & DDT & Total & $\alpha-\mathrm{HCH}$ & $\gamma-\mathrm{HCH}$ & PAH & РCB \\
\hline \multicolumn{14}{|c|}{ Mytilus edulis } \\
\hline 1 & 0.42 & 7.28 & 0.07 & 0.98 & 66.75 & 3.70 & 6.05 & 12.10 & 21.85 & 1.57 & 4.40 & 3.07 & 653.50 \\
\hline 2 & 0.66 & 7.58 & 0.10 & 1.90 & 75.25 & 4.10 & 15.15 & 9.35 & 28.60 & 0.80 & 2.98 & 2.26 & 598.50 \\
\hline 3 & 3.20 & 8.75 & 0.52 & 2.75 & 78.00 & 4.55 & 7.60 & 21.50 & 33.65 & 1.10 & 3.07 & 3.85 & 1286.25 \\
\hline 4 & 4.35 & 8.10 & 0.16 & 2.55 & 121.75 & 13.95 & 19.70 & 17.05 & 50.70 & 0.67 & 4.08 & 9.40 & 3612.25 \\
\hline 5 & 3.85 & 8.33 & 0.13 & 2.90 & 94.75 & 12.70 & 18.15 & 6.90 & 37.75 & 0.67 & 4.58 & 6.77 & 3091.00 \\
\hline 6 & 1.25 & 7.13 & 0.13 & 1.70 & 61.00 & 4.55 & 6.10 & 9.05 & 19.70 & 0.85 & 2.50 & 3.86 & 804.00 \\
\hline 7 & 0.60 & 5.30 & 0.05 & 1.10 & 46.75 & 2.85 & 8.15 & 20.15 & 31.15 & 1.40 & 9.20 & 1.05 & 308.50 \\
\hline 8 & 0.40 & 6.70 & 0.09 & 1.45 & 57.50 & 1.30 & 5.25 & 3.25 & 9.80 & 0.45 & 2.43 & 1.87 & 241.25 \\
\hline 9 & 0.35 & 6.33 & 0.07 & 1.10 & 47.00 & 1.45 & 4.40 & 0.75 & 6.60 & 1.07 & 4.63 & 1.34 & 154.00 \\
\hline 11 & 0.30 & 5.90 & 0.08 & 0.80 & 44.00 & 2.15 & 3.35 & 2.80 & 8.30 & 1.57 & 2.38 & 1.04 & 187.75 \\
\hline 12 & 0.76 & 5.45 & 0.13 & 2.60 & 224.75 & 1.70 & 1.00 & 1.80 & 4.50 & 1.05 & 2.53 & 2.88 & 351.00 \\
\hline 15 & 0.89 & 8.15 & 0.12 & 1.75 & 214.00 & 7.25 & 12.50 & 18.70 & 38.45 & 1.17 & 7.78 & 11.86 & 512.25 \\
\hline 18 & 0.57 & 5.70 & 0.11 & 2.43 & 84.00 & 3.45 & 8.25 & 4.65 & 16.35 & 0.60 & 12.37 & 5.60 & 409.75 \\
\hline 19 & 0.87 & 6.98 & 0.07 & 2.58 & 77.25 & 9.90 & 15.55 & 1.60 & 27.05 & 0.90 & 4.80 & 1.87 & 863.75 \\
\hline 20 & 1.06 & 7.65 & 0.11 & 3.30 & 104.25 & 6.75 & 10.35 & 3.25 & 20.35 & 0.50 & 4.33 & 2.00 & 508.50 \\
\hline \multicolumn{14}{|c|}{ Mytilus galloprovincialis } \\
\hline 34 & 0.74 & 9.00 & 0.12 & 6.60 & 220.67 & 22.65 & 33.15 & 11.95 & 67.75 & 0.43 & 3.18 & 3.68 & 335.00 \\
\hline 35 & 0.95 & 7.58 & 0.05 & 1.50 & 148.75 & 17.00 & 94.65 & 17.85 & 129.50 & 1.27 & 5.27 & 3.73 & 393.50 \\
\hline 36 & 0.74 & 7.35 & 0.06 & 1.70 & 140.50 & 17.20 & 28.55 & 12.10 & 57.85 & 0.73 & 2.55 & 2.91 & 425.75 \\
\hline 37 & 1.09 & 6.30 & 0.11 & 2.30 & 199.00 & 23.75 & 27.45 & 25.95 & 77.15 & 1.15 & 2.88 & 2.52 & 478.25 \\
\hline 38 & 0.39 & 5.48 & 0.05 & 1.55 & 117.00 & 25.85 & 23.00 & 19.30 & 68.15 & 0.93 & 4.63 & 4.50 & 438.50 \\
\hline 39 & 0.52 & 6.70 & 0.21 & 3.10 & 119.00 & 18.10 & 20.35 & 8.40 & 46.85 & 0.43 & 2.58 & 5.33 & 486.75 \\
\hline 40 & 0.71 & 7.73 & 0.53 & 8.33 & 171.00 & 7.75 & 9.05 & 4.40 & 21.20 & 0.40 & 1.70 & 6.65 & 521.25 \\
\hline 41 & 1.07 & 6.85 & 0.20 & 6.05 & 314.25 & 2.70 & 6.60 & 3.85 & 13.15 & 0.85 & 2.70 & 3.86 & 225.25 \\
\hline 42 & 0.61 & 5.53 & 0.10 & 0.40 & 91.25 & 1.80 & 3.20 & 2.50 & 7.50 & 0.77 & 2.67 & 1.50 & 80.50 \\
\hline 43 & 0.53 & 5.15 & 0.13 & 0.75 & 146.50 & 3.45 & 4.95 & 3.35 & 11.75 & 0.80 & 2.97 & 1.83 & 133.25 \\
\hline \multicolumn{14}{|c|}{ Crassostrea gigas } \\
\hline 10 & 2.03 & 142.73 & 0.20 & 1.63 & 2053.33 & 2.15 & 5.50 & 1.95 & 9.60 & 0.70 & 2.98 & 2.66 & 168.75 \\
\hline 13 & 0.98 & 40.68 & 0.08 & 0.83 & 922.50 & 4.60 & 6.50 & 4.70 & 15.80 & 0.80 & 2.00 & 1.85 & 388.75 \\
\hline 14 & 1.09 & 59.45 & 0.15 & 5.93 & 1261.00 & 5.05 & 6.35 & 7.15 & 18.55 & 9.40 & 16.00 & 2.11 & 308.25 \\
\hline 16 & 1.35 & 51.65 & 0.20 & 1.20 & 1952.00 & 2.75 & 5.20 & 10.05 & 18.00 & 1.47 & 8.48 & 1.25 & 237.50 \\
\hline 17 & 1.34 & 128.60 & 0.15 & 1.15 & 2598.75 & 5.60 & 9.95 & 6.05 & 21.60 & 1.07 & 6.23 & 1.61 & 303.25 \\
\hline 21 & 1.82 & 145.68 & 0.26 & 1.60 & 2282.75 & 6.30 & 8.25 & 1.50 & 16.05 & 1.15 & 3.95 & 0.92 & 203.00 \\
\hline 22 & 3.33 & 470.28 & 0.26 & 1.63 & 3803.00 & 11.75 & 17.45 & 1.65 & 30.85 & 1.98 & 6.40 & 1.41 & 207.25 \\
\hline 23 & 2.72 & 191.18 & 0.27 & 1.53 & 2989.00 & 20.55 & 18.60 & 4.60 & 43.75 & 1.68 & 6.33 & 1.52 & 252.25 \\
\hline 24 & 4.79 & 398.83 & 0.30 & 1.73 & 3422.25 & 8.65 & 13.20 & 2.75 & 24.60 & 20.80 & 8.58 & 1.80 & 210.25 \\
\hline 25 & 5.68 & 288.23 & 0.35 & 1.45 & 3860.75 & 8.45 & 21.00 & 3.00 & 32.45 & 10.95 & 7.25 & 1.52 & 256.25 \\
\hline 26 & 11.27 & 314.80 & 0.19 & 1.80 & 2577.75 & 16.75 & 24.10 & 8.95 & 49.80 & 16.20 & 7.43 & 1.54 & 462.25 \\
\hline 27 & 30.17 & 1064.20 & 0.22 & 2.20 & 6062.00 & 18.90 & 68.80 & 11.45 & 99.15 & 14.70 & 6.73 & 2.19 & 500.00 \\
\hline 28 & 55.97 & 985.20 & 0.22 & 2.58 & 3972.25 & 20.60 & 39.90 & 2.05 & 62.55 & 2.20 & 3.43 & 2.44 & 583.25 \\
\hline 29 & 1.90 & 92.98 & 0.17 & 1.40 & 2768.25 & 15.25 & 9.55 & 10.45 & 35.25 & 2.15 & 4.05 & 1.64 & 192.25 \\
\hline 30 & 1.13 & 135.58 & 0.22 & 1.25 & 2717.75 & 16.80 & 14.05 & 9.75 & 40.60 & 1.00 & 3.68 & 3.24 & 143.75 \\
\hline 31 & 2.86 & 335.45 & 0.23 & 2.18 & 3999.25 & 6.55 & 18.10 & 6.05 & 30.70 & 1.63 & 6.98 & 4.28 & 434.25 \\
\hline 32 & 1.36 & 269.45 & 0.18 & 2.43 & 4026.50 & 25.65 & 43.95 & 21.90 & 91.50 & 1.73 & 5.10 & 51.93 & 800.75 \\
\hline 33 & 1.97 & 559.10 & 0.17 & 3.83 & 4881.25 & 10.40 & 37.85 & 14.25 & 62.50 & 3.73 & 4.23 & 17.02 & 971.25 \\
\hline
\end{tabular}


(Sites 26 to 28) contributes to the greatest environmental problem brought to light by the mussel watch program (Boutier \& Chiffoleau 1986). Cadmium body burdens were in the range 10 to $60 \mu \mathrm{g} \mathrm{g}^{-1}$ dry wt of tissues.

High PCB and PAH concentrations were measured in Mytilus edulis in the Seine Estuary (Sites 4 and 5). The measured PAH concentrations were above $6000 \mathrm{ng} \mathrm{g}^{-1}$ dry wt of mussel tissues, and the PCB body burdens exceeded $3000 \mathrm{ng} \mathrm{g}^{-1}$ dry wt of mussel tissues (Table 1). The Seine Estuary is thus one of the most highly polluted sites in the world in regard to such compounds (Minier et al. 2006).

In the Mediterranean Sea, the mussels Mytilus galloprovincialis were mainly characterised by their relatively high levels of DDD, DDE and DDT accumulated in the tissues. The sum of the 3 compounds was 50 to $130 \mathrm{ng} \mathrm{g}^{-1}$ dry wt of mussel tissues for Sites 34 to 39. In contrast, Corsican sites (Sites 42 to 43) had relatively low body burdens for all measured contaminants.

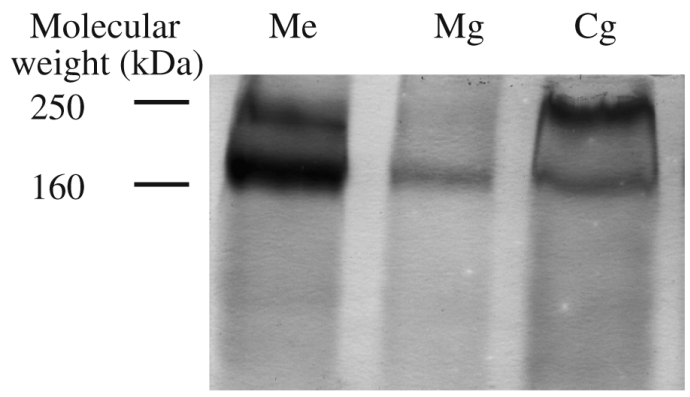

Fig. 2. Western blot of Mytilus edulis (Me), M. galloprovincialis $(\mathrm{Mg})$ and Crassostrea gigas $(\mathrm{Cg})$ protein extracts using the C219 monoclonal antibody

\section{MXR expression levels}

Analysis of the Western blots obtained with the C219 monoclonal antibody showed that mussels Mytilus edulis and M. galloprovincialis and oysters Crassostrea gigas express MXR proteins of approximately 170 and 220 kDa (Fig. 2). Despite some staining responses sometimes found for low molecular weights and likely to correspond to degraded products, the C219 staining was specific as no cross reaction was observed with the whole-cell Prorocentrum micans extracts. The dot blot method was thus used to obtain staining responses related to the protein quantities spotted on nitrocellulose sheets. A significant linear correlation ( $\mathrm{r}=$ 0.92, $\mathrm{p}<0.001, \mathrm{n}=8$ ) between staining intensity and protein quantities was observed in the range of 0.2 to $20 \mu \mathrm{g}$ of proteins.

Fig. 3 shows the MXR-protein expression levels in bivalves across all 43 sites. Significant differences were found for each bivalve species in relation to the sampling sites $(p<0.05)$. Although comparisons might not be valid between species, analysis of the results showed highest expression levels in the Seine Bay and a little further north, at 2 sites in Brittany, at the Loire and Gironde estuaries and in the Mediterranean Sea (with the noteworthy exception of the Corsican sitesSites 42 and 43).

\section{Statistical analysis}

Multivariate analysis of oyster data did not show any significant differences between MXR protein expression and contaminant burden. However, multivariate

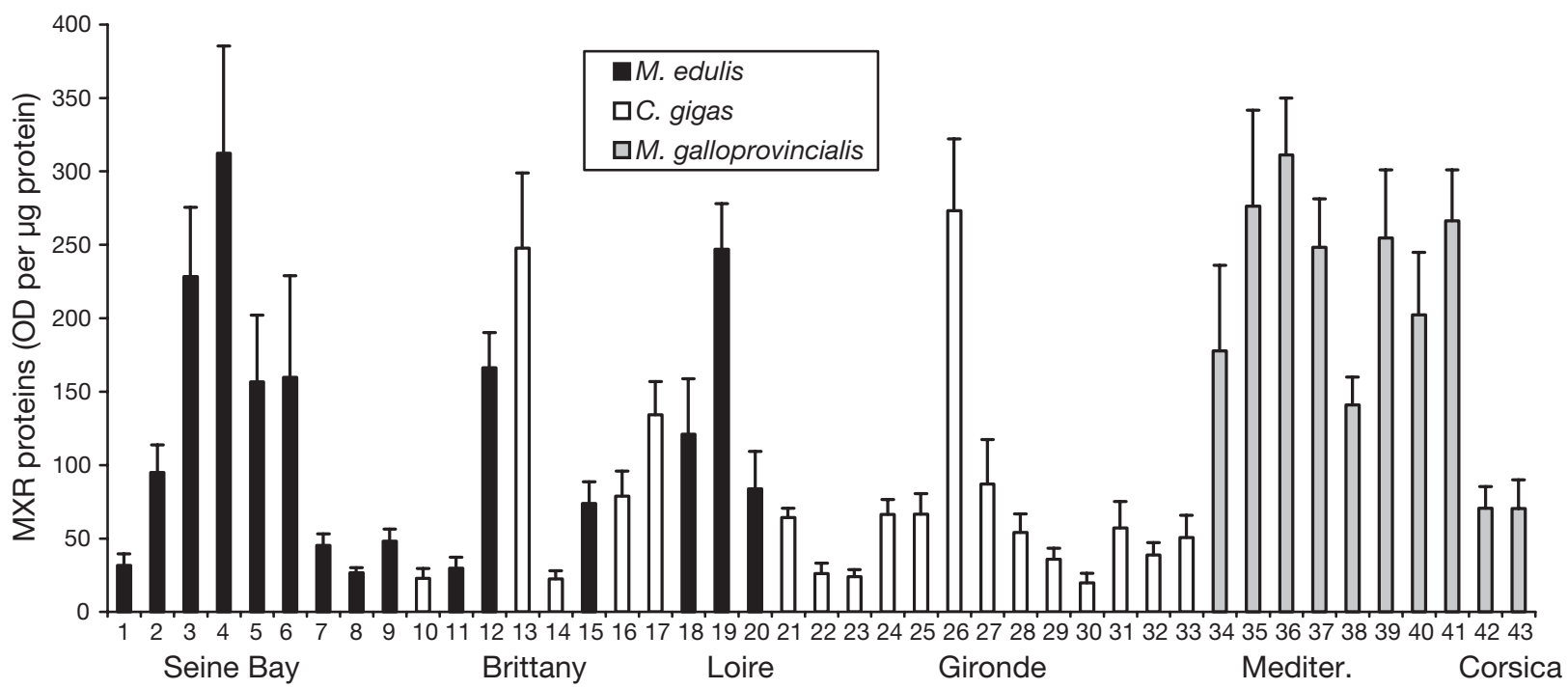

Fig. 3. Mytilus edulis, M. galloprovincialis and Crassostrea gigas. MXR-protein expression levels in mussel and oyster gills along the French coasts. Bars indicate 95\% confidence intervals. OD: optical density 

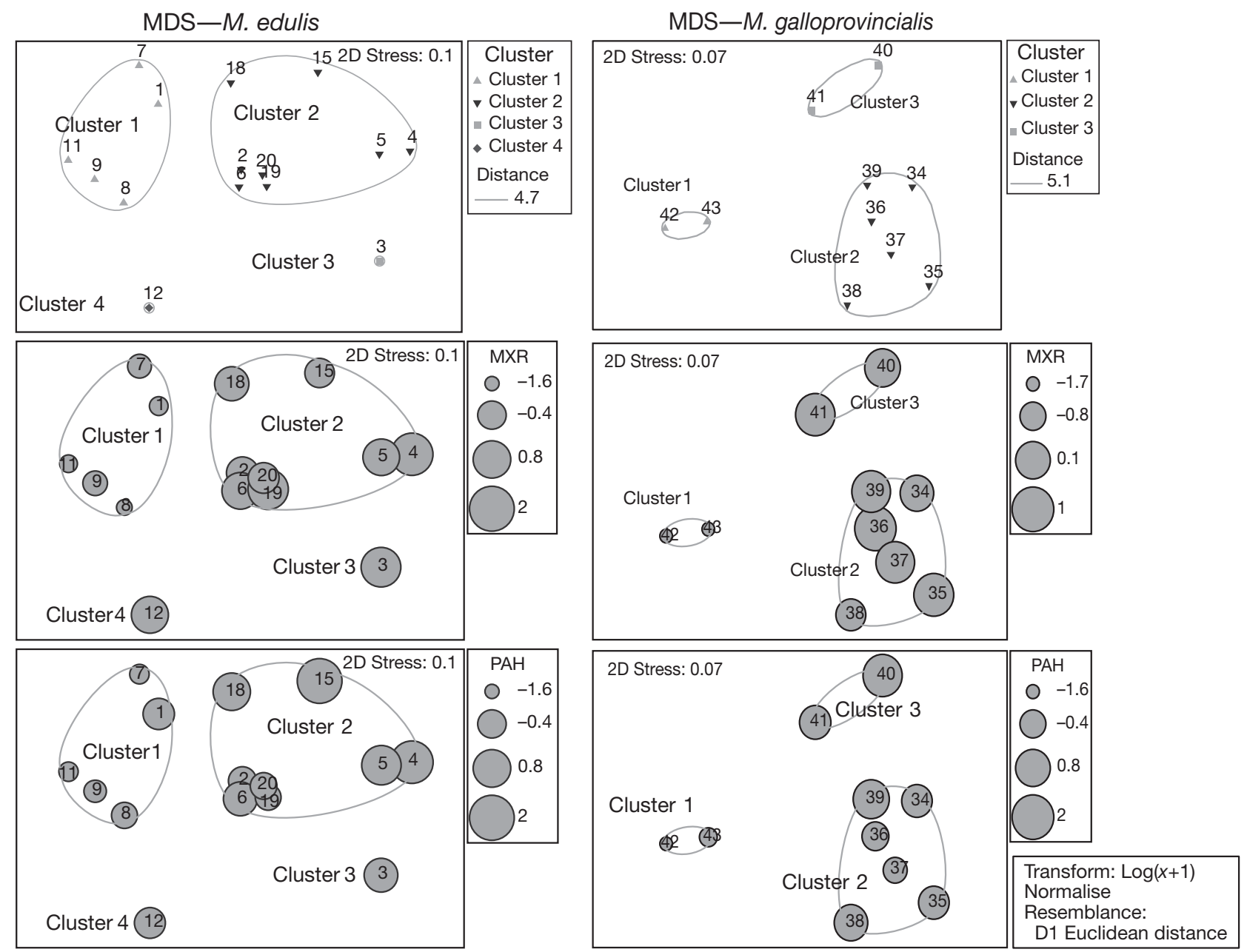

Fig. 4. Mytilus edulis and M. galloprovincialis. Results of multivariate analysis of MXR protein and all measured contaminants for both species of blue mussel. Non-metric multidimensional scaling analysis with superimposed cluster analysis indicates 4 distinct groups for $M$. edulis (MDS stress 0.1) and 3 for M. galloprovincialis (MDS stress 0.07). Bubble plots are shown for MXR protein expression and PAHs only as representative ubiquitous indicators of pollution

analysis using MDS, cluster analysis and ANOSIM of blue mussel data did show significant differences between groups of samples when the MXR protein and all of the pollutant data were analysed together for Mytilus edulis and M. galloprovincialis respectively (Fig. 4, Table 2). These findings indicate that that increased MXR protein is significantly associated with increased pollution in both species of mussel.

Since previous data have indicated that induction of MXR protein is linked with PAHs and PCBs, the data sets were reanalysed using only MXR protein, $\mathrm{PAH}$ and $\mathrm{PCB}$ concentrations. The results of these analyses are shown in Fig. 5; there is a general similarity to the clusters obtained using all of the pollutant data (MDS stress values are reduced in comparison with the full data sets). Sites 4 and 5 at the mouth of the Seine (Mytilus edulis from Le Havre and Villerville) are a distinct group in Cluster 4 (Fig. 5); both sites are characterised by the highest tissue concentrations of cadmium, PCBs and PAHs.
Table 2. Mytilus edulis and M. galloprovincialis. ANOSIM 1-way analysis of similarity ( $\mathrm{R}$ statistic) for blue mussel data (only statistically significant comparisons are shown)

\begin{tabular}{|c|c|c|c|c|}
\hline Variables & $\begin{array}{c}\text { Global } \\
\text { test }\end{array}$ & $\begin{array}{l}\text { Clusters } \\
1 \& 2\end{array}$ & $\begin{array}{l}\text { Clusters } \\
1 \& 4\end{array}$ & $\begin{array}{l}\text { Clusters } \\
2 \& 4\end{array}$ \\
\hline $\begin{array}{l}\text { Mytilus edulis } \\
\text { All parameters }\end{array}$ & $\begin{array}{l}R=0.764 \\
p \leq 0.001\end{array}$ & $\begin{array}{l}\mathrm{R}=0.683 \\
\mathrm{p} \leq 0.002\end{array}$ & & \\
\hline $\begin{array}{l}\text { MXR protein, } \\
\text { PAH, PCB }\end{array}$ & $\begin{array}{l}\mathrm{R}=0.919 \\
\mathrm{p} \leq 0.001\end{array}$ & $\begin{array}{l}\mathrm{R}=0.876 \\
\mathrm{p} \leq 0.001\end{array}$ & $\begin{array}{l}\mathrm{R}=1.000 \\
\mathrm{p} \leq 0.048\end{array}$ & $\begin{array}{l}\mathrm{R}=0.948 \\
\mathrm{p} \leq 0.028\end{array}$ \\
\hline $\begin{array}{l}\text { Mytilus gallopr } \\
\text { All parameters }\end{array}$ & $\begin{array}{l}\text { vincialis } \\
R=0.824 \\
p \leq 0.002\end{array}$ & $\begin{array}{l}R=1.000 \\
p \leq 0.036\end{array}$ & & \\
\hline $\begin{array}{l}\text { MXR protein, } \\
\text { PAH, PCB }\end{array}$ & $\begin{array}{l}\mathrm{R}=1.000 \\
\mathrm{p} \leq 0.022\end{array}$ & $\begin{array}{l}\mathrm{R}=1.000 \\
\mathrm{p} \leq 0.022\end{array}$ & & \\
\hline \multicolumn{5}{|c|}{ Combined species } \\
\hline $\begin{array}{l}\text { MXR protein } \\
\text { PAH, PCB }\end{array}$ & $\begin{array}{l}\mathrm{R}=0.870 \\
\mathrm{p} \leq 0.001\end{array}$ & $\begin{array}{l}\mathrm{R}=0.858 \\
\mathrm{p} \leq 0.001\end{array}$ & $\begin{array}{l}\mathrm{R}=0.996 \\
\mathrm{p} \leq 0.022\end{array}$ & $\begin{array}{l}\mathrm{R}=0.976 \\
\mathrm{p} \leq 0.010\end{array}$ \\
\hline
\end{tabular}




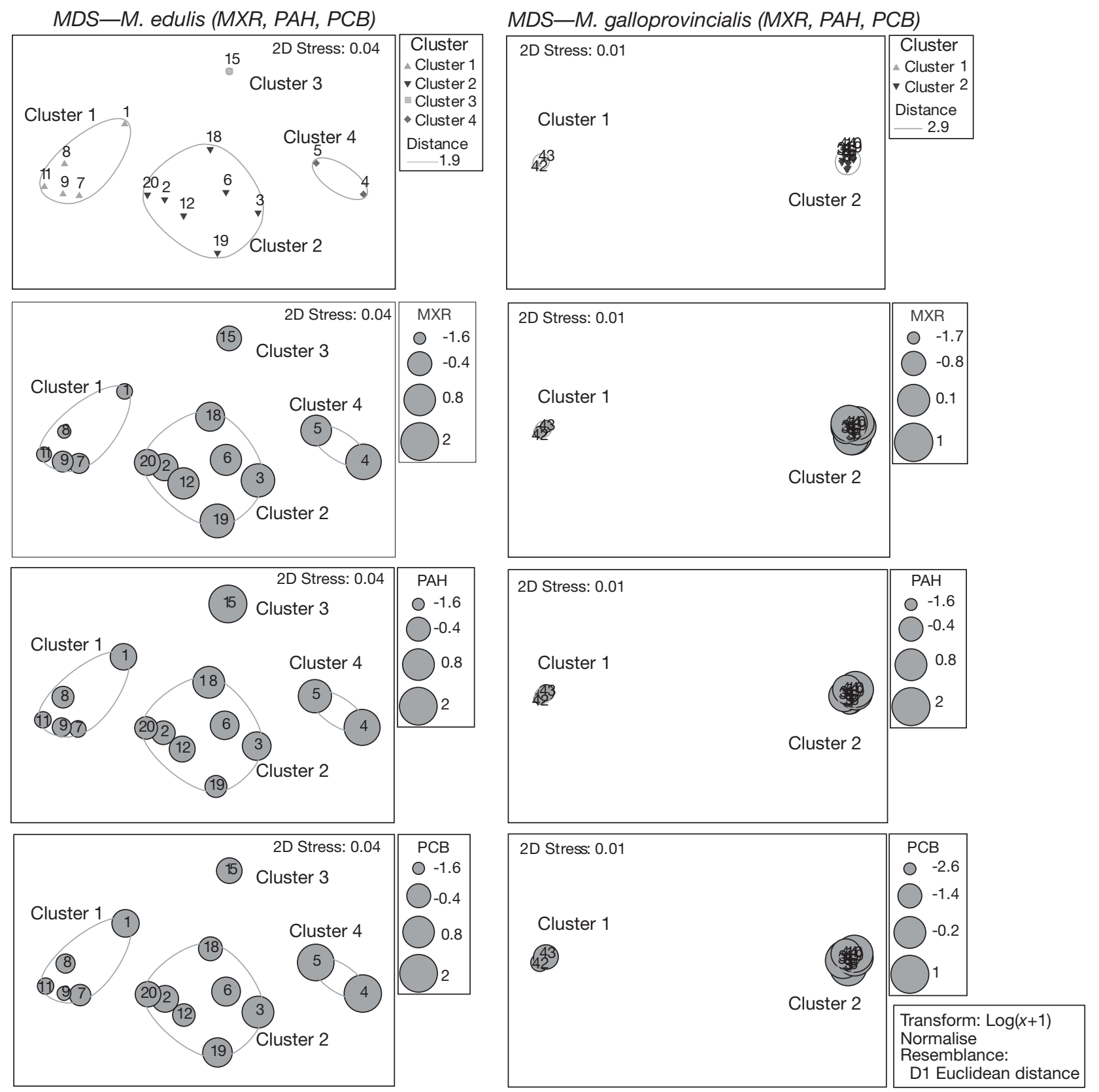

Fig. 5. Mytilus edulis and M. galloprovincialis. MDS and superimposed cluster analysis for MXR protein, PAHs and PCBs only. Cluster analysis indicates 4 distinct groups for $M$. edulis and 2 groups for $M$. galloprovincialis. Bubble plots are shown for MXR protein expression, PAHs and PCBs

ANOSIM indicated significant differences between the relatively less-contaminated sites in Cluster 1 for both species compared with the more contaminated clusters (Table 2, Fig. 5). Spearman rank correlations derived from the BIOENV routine indicated that the 3 parameters essentially captured the full MDS profile for both species of blue mussel (Table 3).

MDS and cluster analysis of combined species data for MXR protein, PAHs and PCBs from both species of blue mussels essentially showed a simple combination of the separate analyses (Figs. 6 \& 7). ANOSIM showed that there were significant differences between Cluster 1 and Clusters 2 and 4, as well as between Clusters 2 and 4 (Table 2, Fig. 7). The only noticeable difference in the MDS plot was a shift for Sites 2 and 20 from Cluster 2 in the Mytilus edulis analysis to Cluster 1 in the combined analysis; and again, Sites 4 and 5 at the mouth of the Seine formed a distinct cluster. These analyses indicate that it was probably a reasonable assumption to treat both closely related species together. 
Table 3. Mytilus edulis and M. galloprovincialis. Spearman rank correlations (PRIMER ver. 6 BIOENV) for separate and combined blue mussel data. Variables: (1) MXR protein; (2) PAHs; (3) PCBs

\begin{tabular}{|lcc|}
\hline Number of variables & Correlation & Selections \\
\hline Mytilus edulis & & \\
3 & 1.000 & $1,2,3$ \\
2 & 0.913 & 1,2 \\
2 & 0.857 & 2,3 \\
2 & 0.825 & 1,3 \\
Mytilus galloprovincialis & & \\
3 & 1.000 & $1,2,3$ \\
2 & 0.961 & 1,2 \\
2 & 0.948 & 2,3 \\
2 & 0.816 & 1,3 \\
Combined species & & \\
3 & 1.000 & $1,2,3$ \\
2 & 0.871 & 1,2 \\
2 & 0.869 & 1,3 \\
2 & 0.838 & 2,3 \\
\hline
\end{tabular}

\section{DISCUSSION}

Immunochemical analyses have proven very useful and accurate in assessing multixenobiotic resistance protein expression levels in mammals (Fredericks et al. 1991), and such experiments have been proposed as a tool for assessing the cell degree of resistance (Chan et al. 1990) and for predicting the response of tumour cells to chemotherapy (Leonard et al. 2003, Efferth \& Volm 2005). In this study, MXR expression was assessed in both mussels and oysters along the French coasts. High P-glycoprotein concentrations were found in samples collected in the Seine Bay and the Loire and Gironde estuaries, which are likely to be areas impacted by numerous xenobiotics carried by the rivers. High expression levels were also found in nearly all sites from the Mediterranean mainland coasts, and multivariate analysis of pooled blue mussel data did show that expression of MXR protein was strongly associated with contaminant concentrations in mussels. With the exception of results from the Mediterranean Sea, a similar pattern of biological response has previously been observed with other biomarkers such as P-450-mediated ethoxyresorufin Odeethylase activity (Burgeot et al. 1994), acetylcholineesterase activity (Bocquené et al. 1993) and the micronucleus assay (Burgeot et al. 1995).

The physiological function of Pgp is not known in detail but might include detoxification and excretion of xenobiotics (Bodo et al. 2003). Differential MXR protein levels in bivalves might be related to the presence of toxic compounds inducing its expression as seen in mammals. Indeed, in knockout mice, which lack various P-glycoprotein isoforms, tissue distribution and elimination of drugs are affected (Schinkel et al. 1994). A 2- to 20-fold increase in accumulation and subsequent increase in toxicity have been reported in various organs when compared with wild type mice, demonstrating that these proteins are essential in preventing the accumulation of xenobiotics in multiple organs. Similarly, mussel MXR proteins are induced by exposure to toxic compounds (Minier \& Moore 1996,

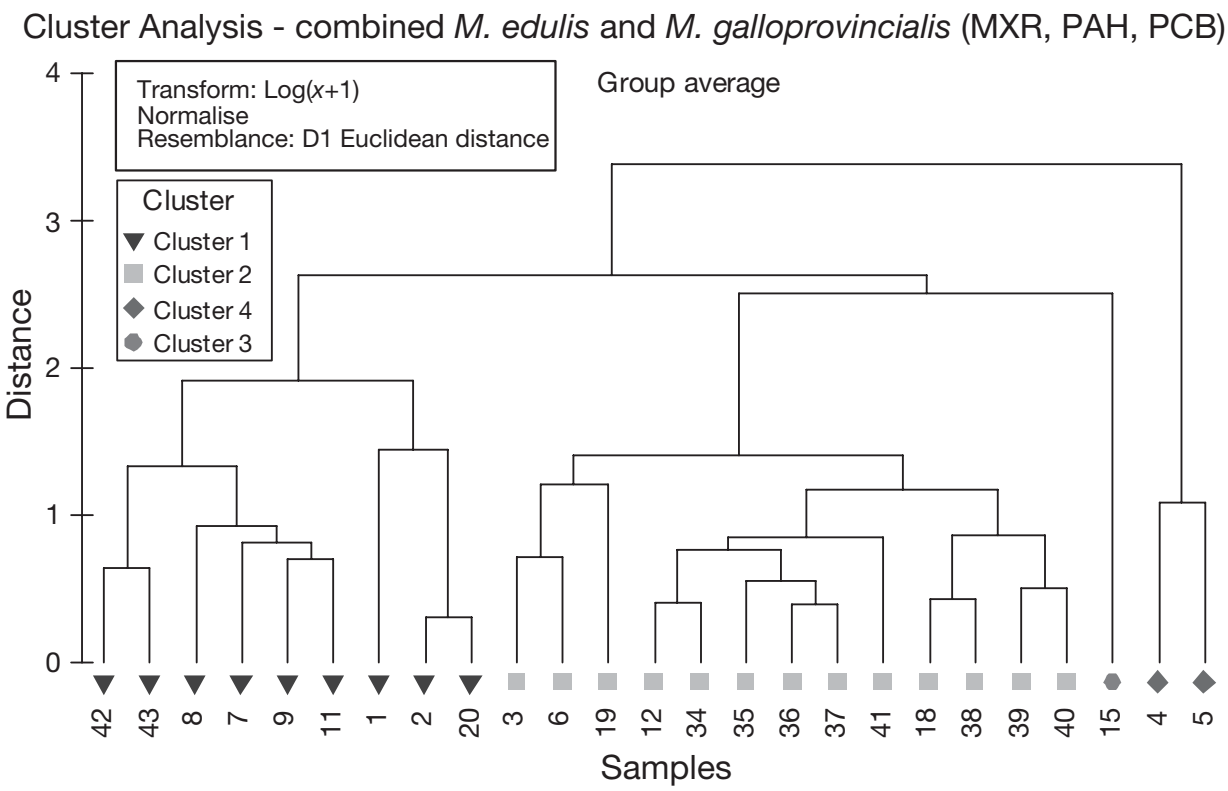

Fig. 6. Mytilus edulis and M. galloprovincialis. A dendrogram derived from cluster analysis for combined mussel data for MXR protein, PAHs and PCBs. Sites 1-9, 11, 12, 15 and 18-20 are M. edulis and Sites 34-43 are M. galloprovincialis 
MDS—combined M. edulis and M. galloprovincialis (MXR, PAH, PCB)
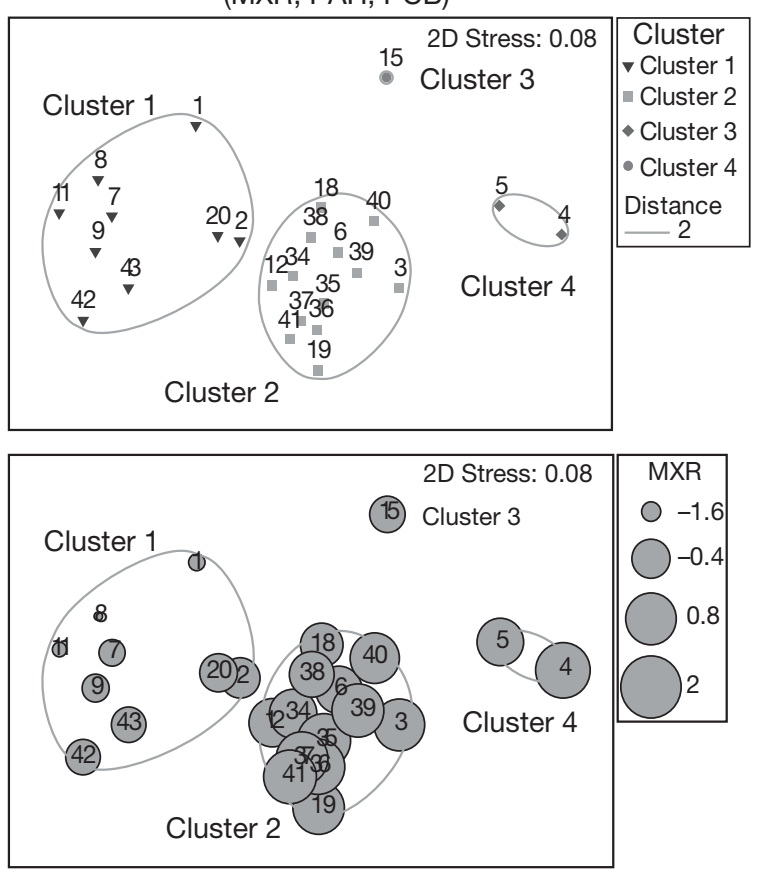

MDS—combined $M$. edulis and $M$. galloprovincialis (MXR, PAH, PCB)
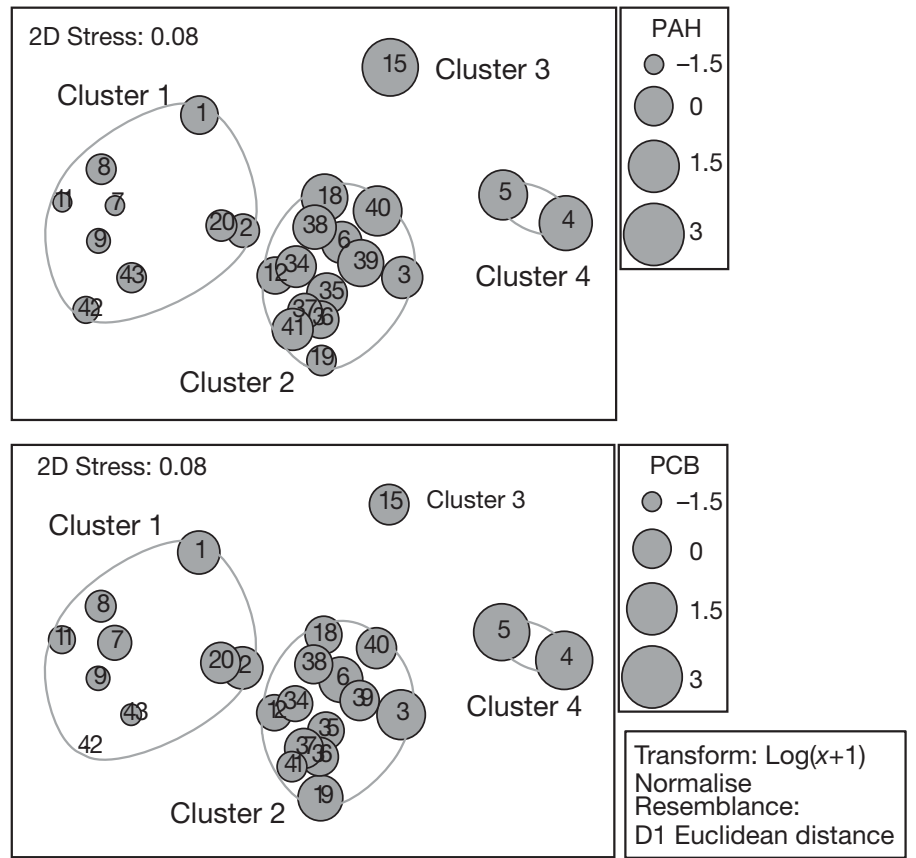

Fig. 7. Mytilus edulis and M. galloprovincialis. MDS (stress 0.08) and superimposed cluster analysis for MXR protein, PAHs and PCBs only in combined data for both species of blue mussel. Cluster analysis indicates 4 distinct groups. Bubble plots are shown for MXR protein expression, PAHs and PCBs

Smital et al. 2003). In this study, the results of the multivariate analysis show clearly that MXR protein is strongly correlated with PAHs and PCBs. This does not imply a causal linkage, since it is probable that many other chemical contaminants, not included in the chemical determinations, are also present at some sites. However, exposure to PAHs has been implicated in induction of MXR expression in mussels (Kurelec 1995, Smital et al. 2003) and other organisms (Hamdoun et al. 2002). To our knowledge, PCBs have not yet been used as inducers in vitro. But studies on mussels have already shown that these compounds can interact with the mussel MXR system, thus altering membrane transport. In Mytilus galloprovincialis, PCBs compete with rhodamine (a known Pgp substrate), leading to an increase in either dye accumulation or impaired export (Galgani et al. 1995). In M. californianus, the same effects on rhodamine transport were also correlated with MXR protein titer (Eufemia \& Epel 1998).

No correlation was observed for Crassostrea gigas between MXR content and contaminant concentrations. In the oyster $C$. virginica, Keppler \& Ringwood (2001) also failed to find any correlation between MXR proteins and pollutants in another field study. Differences in organism physiology or in site characteristics might explain these discrepancies. In this study, sites where oysters were collected were characterised by their high levels of metal contamination (especially cadmium, copper and zinc) as indicated by the mollusc body burdens. This specific pattern of contaminants may contribute to the absence of correlation, although cadmium has been shown to induce Pgp expression in other mollusc species (Eufemia \& Epel 2000, Legeay et al. 2005).

The results of the multivariate analysis show clearly that MXR protein expression can be used as an indicator of pollutant exposure in blue mussels, but not oysters (at least in this study); and that up-regulated MXR protein expression is strongly linked with elevated contaminant burdens of PAHs and PCBs (Fig. 8). The findings demonstrate that multi-dimensional data can be effectively represented in a 2-dimensional way using multi-dimensional scaling. Empirical evidence and simulation studies of MDS stress values indicate that stress increases not only with reducing dimensionality but also with increasing quantity of data (Clarke \& Warwick 2001). A general rule is that stress values less than 0.1 correspond to a good ordination with no real prospect of a misleading interpretation, and values $<0.05$ give an excellent representation with no prospect of misrepresentation (a perfect representation would probably be one with stress values $<0.01$ ). Since all of the MDS-derived stress values were between 0.01 and 0.1 , the interpretations are probably reasonable. 

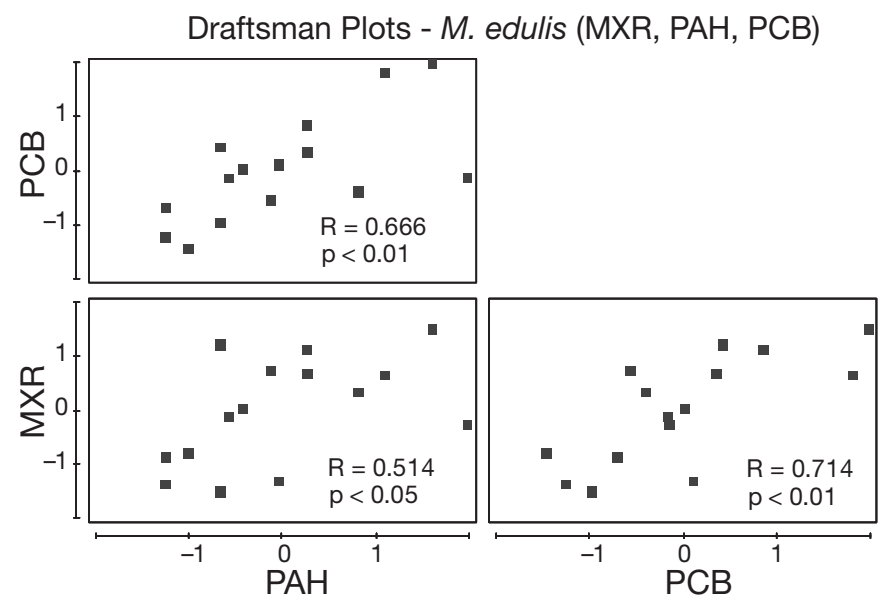

Draftsman Plots - M. galloprovincialis (MXR, PAH, PCB)

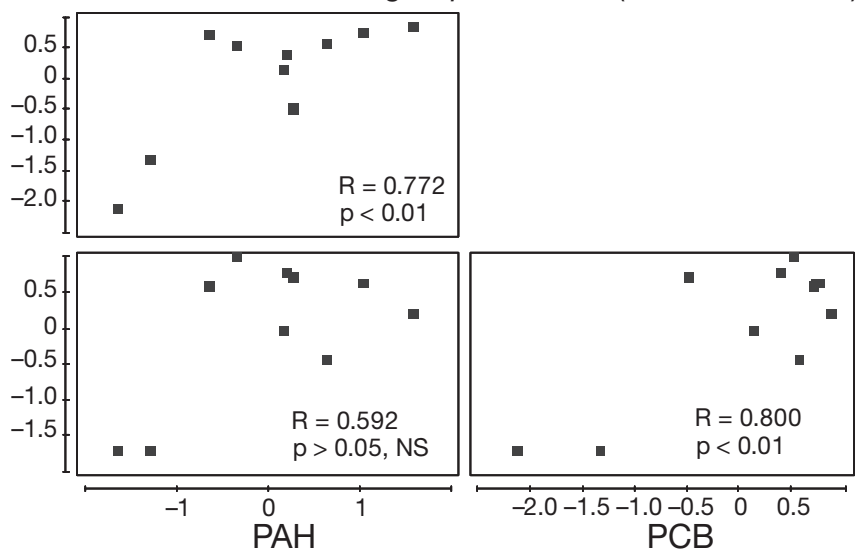

Draftsman Plots - combined $M$. edulis and $M$. galloprovincialis (MXR, PAH, PCB)
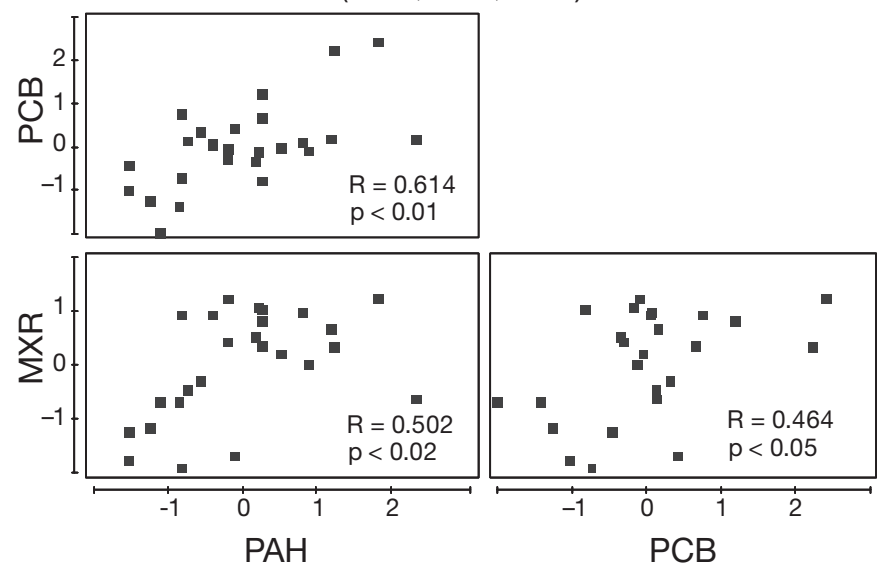

Fig. 8. Mytilus edulis and M. galloprovincialis. Draftsman plots for both species of blue mussel and combined data for MXR expression, PAHs and PCBs. Standard product moment correlation coefficients between every pair of variables are shown on each plot. It is clear from these pairwise scatterplots that MXR expression and concentration of PAHs and PCBs are correlated (all significant at $\mathrm{p}<0.05$, except for MXR vs PAH for M. galloprovincialis)
The selection of PAHs and PCBs as toxicologically meaningful variables along with MXR protein for MDS had the effect of reducing the stress in all cases.

The cluster and MDS analysis identifies mussels with either high or low MXR protein content. It also consistently shows that the samples from the mouth of the Seine (Sites 4 and 5) have different characteristics from the other groups (Figs. 4, $5 \& 7$ ). Since these animals (Sites 4 and 5) were characterised by the highest tissue concentrations of cadmium, PCBs and PAHs, a possible explanation may lie in the existence of a maximum MXR protein expression level that is reached when contaminant concentrations are high or, otherwise, through antagonistic interactions between contaminants. As the MXR transport mechanism is capable of saturation (Toomey \& Epel 1993), doses exceeding the maximum induction level or the presence of compounds that interfere with normal MXR expression may endanger the health of the animals.

Overall, the findings highlight the need to use alternative analytical methods for the interpretation of complex environmental data, and that non-parametric multivariate statistical methods are appropriate for this task (Wedderburn et al. 1998, Astley et al. 1999, Galloway et al. 2002, Allen \& Moore 2004).

Acknowledgements. The authors are grateful to B. Belaief and M. R. Carr for their help in statistical analysis, to L. Giboire for drawing and to T. Burgeot and A. Grouhel for their technical and scientific support. M.N.M. was supported in this study by the Department for Environment, Food \& Rural Affairs (Defra, UK) as part of the PREDICT 2 Project (Contract No. AE1136).

\section{LITERATURE CITED}

Akiyama SI, Fojo A, Hanover JA, Pastan I, Gottesman MM (1985) Isolation and genetic characterization of human KB cell lines resistant to multiple drugs. Somatic Cell Mol Genet 11:117-126

Allen JI, Moore MN (2004) Environmental prognostics: is the current use of biomarkers appropriate for environmental risk evaluation? Mar Environ Res 58:227-232

Astley KH, Meigh HC, Glegg GA, Braven J, Depledge MH (1999) Multivariate analysis of biomarker responses in Mytilus edulis and Carcinus maenas from the Tees Estuary (UK). Mar Pollut Bull 39:1-12

Bard SM (2000) Multixenobiotic resistance as a cellular defense mechanism in aquatic organisms. Aquat Toxicol 48:357-389

Biedler JM, Riehm H (1970) Cellular resistance to actinomycin D in Chinese hamster cells in vitro: cross-resistance, radioautographic and cytogenetic studies. Cancer Res 30: $1174-1184$

Bocquené $\mathrm{G}$, Burgeot $\mathrm{T}$, Le Dean $\mathrm{L}$, Truquet $\mathrm{P}$, Galgani $\mathrm{F}$ (1993) Acetylcholinesterase levels in fishes along the French coasts. Mar Pollut Bull 26:101-106

Bodo A, Bakos E, Szeri F, Varadi A, Sarkadi B (2003) The role of multidrug transporters in drug availability, metabolism and toxicity. Toxicol Lett 140-141:133-143 
Boutier B Chiffoleau JF (1986) La contamination par le cadmium en Gironde et son extension sur le plateau continental. Rapport IFREMER, DERO-86.12-MR. IFREMER Brest

Burgeot T, Bocquené G, Pingray G, Godefroy D and 7 others (1994) Monitoring biological effects of contamination in marine fish along French coasts by measurement of EROD activity. Ecotox Environ Safe 29:131-147

Burgeot T, His E, Galgani F (1995) The micronucleus assay in Crassostrea gigas for the detection of seawater genotoxicity. Mutat Res 342:125-140

Cantillo AY (1998) Comparison of results of mussel watch programs of the United States and France with worldwide mussel watch studies. Mar Pollut Bull 36:712-717

Chan HSL, Thorner PS, Haddad G, Ling V (1990) Immunohistochemical detection of P-glycoprotein: prognostic correlation in soft tissue sarcoma of childhood. J Clin Oncol 8: 689-704

Claisse D (1989) Chemical contamination of French coasts: the results of ten years mussel watch. Mar Pollut Bull 20: 523-528

Clarke KR (1999) Non-metric multivariate analysis in community-level ecotoxicology. Environ Toxicol Chem 18: $117-127$

Clarke KR, Warwick RM (2001) Change in marine communities: an approach to statistical analysis and interpretation. PRIMER-E, Plymouth

Cordon-Cardo C, O'Brien JP, Boccia J, Casals D, Bertino JR, Melamed MR (1990) Expression of the multidrug resistance gene product (P-glycoprotein) in human normal and tumor tissues. J Histochem Cytochem 38:1277-1287

Efferth T, Volm M (2005) Pharmacogenetics for individualized cancer chemotherapy. Pharmacol Therapeut 107:155-176

Eufemia N, Epel D (1998) The multixenobiotic defense mechanism in mussels is induced by substrates and non-substrates: implication for a general stress response. Mar Environ Res 46:401-405

Eufemia N, Epel D (2000) Induction of the multixenobiotic defense mechanism (MXR), P-glycoprotein, in the mussel Mytilus californianus as a general cellular response to environmental stresses. Aquatic Toxicol 49:89-100

Farrington JW, Goldberg ED, Risebrough RW, Martin JH, Bowen VT (1983) U.S. 'mussel watch' 1976-1978: an overview of trace-metal, DDE, PCB, hydrocarbon and artificial radionucleotide data. Environ Sci Technol 17: 490-496

Fredericks WJ, Chen Y, Baker RM (1991) Immunoblot detection of P-glycoprotein in human tumors and cell lines. Cancer Treat Res 57:121-149

Galgani F, Cornwall R, Toomey BH, Epel D (1995) Interaction of environmental xenobiotics with a multixenobiotic defense mechanism in the bay mussel Mytilus galloprovincialis from the coast of California. Environ Toxicol Chem 15:325-331

Galloway TS, Sanger RC, Smith KL, Fillmann G, Readman JW, Ford TE, Depledge MH (2002) Rapid assessment of marine pollution using multiple biomarkers and chemical immunoassays. Environ Sci Technol 36:2219-2226

Georges E, Bradley G, Gariepy J, Ling V (1990) Detection of P-glycoprotein isoforms by gene specific monoclonal antibodies. Proc Natl Acad Sci USA 87:152-156

Gosling E (1992) The mussel Mytilus: ecology, genetics and culture. Elsevier, Amsterdam, p 425-464

Gottesman MM, Pastan I (1993) Biochemistry of multidrug resistance mediated by the multidrug transporter. Annu Rev Biochem 62:385-427

Hamdoun AM, Griffin FJ, Cherr GN (2002) Tolerance to biodegraded crude oil in marine invertebrate embryos and larvae is associated with expression of a multixenobiotic resistance transporter. Aquatic Toxicol 61:127-140

Keppler CJ, Ringwood AH (2001) Expression of P-glycoprotein in southeastern oysters, Crassostrea virginica. Mar Environ Res 52:81-96

Kurelec B (1995) Reversion of multixenobiotic resistance mechanism in gills of a marine mussel Mytilus galloprovincialis by model- and environmental-inhibitors of P170-glycoprotein. Aquat Toxicol 33:93-103

Kurelec B, Krca S, Lucic D (1996) Expression of multixenobiotic resistance mechanism in a marine mussel Mytilus galloprovincialis as a biomarker of exposure to polluted environments. Comp Biochem Physiol 113C:283-289

Lage H (2003) ABC-transporters: implications on drug resistance from microorganisms to human cancers. Int J Antimicrob Ag 22:188-199

Legeay A, Achard-Joris M, Baudrimont M, Massabuau JC, Bourdineaud JP (2005) Impact of cadmium contamination and oxygenation levels on biochemical responses in the Asiatic clam Corbicula fluminea. Aquat Toxicol 74: 242-253

Leonard GD, Fojo T, Bates SE (2003) The role of ABC transporters in clinical practice. Oncologist 8:411-424

Luçon M, Michel P (1986) Dosage des PCB, pesticides et détermination de la quantité de matière extractible à l'hexane dans la chair de poisson. Rapport IFREMER, DERO-86-05-MR, Brest

Lüdeking A, Köhler A (2002) Identification of six mRNA sequences of genes related to multixenobiotic resistance (MXR) and biotransformation in Mytilus edulis. Mar Ecol Prog Ser 238:115-124

Michel P (1983) Dosage global des hydrocarbures aromatiques dans les organismes marins par CLHP fluorescence. In: Aminot A, Chaussepied M (eds) Manuel des analyses chimiques en milieu marin. IFREMER, Paris, p 337-346

Minier C, Moore MN (1996) Rhodamine B accumulation and MXR protein expression in mussel blood cells: effects of exposure to vincristine. Mar Ecol Prog Ser 142:165-173

Minier C, Akcha F, Galgani F (1993) P-glycoprotein expression in Crassostrea gigas and Mytilus edulis in polluted seawater. Comp Biochem Physiol 106:1029-1036

Minier C, Lelong C, Djemel N, Rodet F, Tutundjian R, Favrel P, Mathieu M, Leboulenger F (2002) Expression and activity of a Multixenobiotic resistance system in the Pacific oyster Crassostrea gigas. Mar Environ Res 54:455-459

Minier C, Abarnou A, Le Guellec AM, Jaouen-Madoulet A, Tutundjian R, Bocquené $G$, Leboulenger $F$ (2006). A pollution monitoring pilot study involving chemical analysis and biomarker measurements in the Seine estuary using zebra mussels (Dreissena polymorpha). Environ Toxicol Chem. 25:112-119

Moore MN, Depledge MH, Readman JW, Leonard DRP (2004) An integrated biomarker-based strategy for ecotoxicological evaluation of risk in environmental management. Mutat Res 552:247-248

O'Connor TP (2002) National distribution of chemical concentrations in mussels and oysters in the USA. Mar Environ Res 53:117-143

Philips DJH (1978) Use of biological indicator organisms to quantitate organochlorine pollutants in aquatic environments: a review. Environ Pollut 16:167-229

Provasoli L, McLaughlin JJA, Droop MR (1957) The development of artificial media for marine algae. Arch Microbiol 25:392-428

Schinkel AH, Jonker JW (2003) Mammalian drug efflux transporters of the ATP binding cassette (ABC) family: an overview. Adv Drug Deliv Rev 55:3-29 
Schinkel AH, Smit JJ, van Tellingen O, Beijnen JH, Wagenaar E (1994) Disruption of the mouse mdr1a P-glycoprotein gene leads to a deficiency in the blood-brain barrier and to increased sensitivity to drugs. Cell 77:491-502

Smital T, Sauerborn R, Hackenberger BK (2003) Inducibility of the P-glycoprotein transport activity in the marine mussel Mytilus galloprovincialis and the freshwater mussel Dreissena polymorpha. Aquatic Toxicol 65: 443-465

Smital T, Luckenbach T, Sauerborn R, Hamdoun AH, Vega RL, Epel D (2004) Emerging contaminants - pesticides, PPCPs, microbial degradation products and natural substances as inhibitors of multixenobiotic defense in aquatic organisms. Mutat Res 552:101-117

Thibaud Y (1983a) Dosage du mercure dans les organismes marins. In: Aminot A, Chaussepied M (eds) Manuel des

Editorial responsibility: Otto Kinne (Editor-in-Chief), Oldendorf/Luhe, Germany analyses chimiques en milieu marin. IFREMER, Paris, p 243-249

Thibaud Y (1983b) Dosage de métaux (Cu, Zn, Fe, Pb, Cd) dans les organismes marins par absorption atomique. In: Aminot A, Chaussepied $M$ (eds) Manuel des analyses chimiques en milieu marin. IFREMER, Paris, p 250-265

Toomey BH, Epel D (1993) Multidrug resistance in Urechis caupo embryos: protection from environmental toxins. Biol Bull (Woods Hole) 185:355-364

Wedderburn J, Cheung V, Bamber S, Bloxham M Depledge MH (1998) Biomarkers of histochemical and cellular stress in Carcinus maenas: an in situ field study. Mar Environ Res 46:321-324

Whitehead TP, Kricka LJ, Carter JN, Thorpe HG (1979) Analytical luminescence: its potential in the clinical laboratory. Clin Chem 25:1531-1546

Submitted: December 21, 2005; Accepted: March 15, 2006 Proofs received from author(s): September 11, 2006 